\title{
गुँलाधर्म एक परिचय
}

पूर्णलक्ष्मी शाक्य*

\section{सारसंक्षेप}

काठमाडौँ उपत्यकामा महायान बुद्धर्मको बाहुल्यता रहेको छ। यहाँ नेवार समुदायको बसोवास आदिकालदेखि रहेको देखिन्छ। त्यसैले यिनीहरू महायान बुद्धर्मका अनुयायीहरू हुन्। यी नेवार समुदायले वर्ष दिनमा थुप्रै जात्रा पर्वहरू मनाउने गर्दछन्। यसमध्ये चन्द्रमास अनुसारको गुँला महिनामा एक महिना भरि पर्वको रूपमा गुँलाधर्म अभ्यास गर्ने गर्दछन्। यो महिना वर्षा वाढी पहिरो जस्ता प्राकृतिक प्रकोप र रोग व्याधि फैलने महिना हो। त्यसैले यस्तो सम्भावित आपद विपदबाट जोगिन सकियोसू, सबैको मझ़ल होस् भन्ने कामना गरी धर्मकर्म अभ्यास गरेको देखिन्छ। यसको साथसाथै यो महिनामा मानिसहरूले दश अकुशल कर्म त्याग गरी कुशल र शुद्ध जीवन विताउने अभ्यास गर्दछन् ।

शब्दकुज्जी: गुँलाधर्म, गुँला, मतया:; दानधर्म, चाडपर्व

\section{अनुसन्धानको समस्या र उद्देश्य}

उपत्यकाको सबै शहरमा एक महिनासम्म मनाइने गरेको गुँला पर्व साँस्कृतिक धरोहरको रूपमा रहेको छ। यहाँ आदिकालदेखि बसोवास गर्ने नेवार समुदायले मनाउने गरेको धार्मिक पर्व तथा जात्राहरू धार्मिक र मनोरजनात्मक मात्र नभएर समय, परिस्थिती, मौसम र स्वास्थ्यको दृष्टिकोणले समेत महत्त्वपूर्ण र परिकृष्ट रहेको देखिन्छ। यो गुँलापर्वमा धार्मिक रूपमा नवग्रन्थ वाचन र व्याख्या गर्ने, स्तोत्र धारणी आदि पाठ गर्ने, ज्ञानमाला भजन गर्ने गरिन्छ भने तात्त्रिक, सांस्कृतिक, पुरातात्विक महत्त्वका वस्तुहरूको प्रदर्शनी गर्ने गरिन्छ, जुन अरु बेला हेर्न पाइँदैन। त्यस्तै ऐतिहासिक पक्ष भन्नु पर्दा शाक्यमुनि बुद्धको बुद्धत्व प्राप्ती, बुद्धको पूर्व जन्मको जातककथा र स्वयम्भूपुराणसँग सम्बन्ध देखाउँछ। तर हाल समाजमा यी दार्शनिक, ऐतिहासिक, तथा धार्मिक पक्षमा अनभिज्ञ भइसकेको छ। पहिलेदेखि चलि आएको परम्पराको रूपमा जात्रा पर्वलाई निरन्तरता दिएको पाइन्छ। त्यसैले यी पक्षहरूबारे प्रकाश पार्ने उद्देश्य यस लेखमा रहेको छ।

\section{अनुसन्धानको विधि}

यो अनुसन्धान गुणात्मक र विवरणात्मक रहेको छ। यस रचनाको लागि विभिन्न धार्मिक कार्यक्रम, व्रत आदिमा सुनाउने कथाहरू प्रत्यक्ष रूपमा आफैले देखेको र मनाउदै आएको जात्रा पर्वको आधार लिईएको छ। यसबारे समय समयमा प्रकाशन भएका पुस्तक तथा लेख रचनाहरूलाई पनि श्रोतको रूपमा लिइएको छ।

* आंशिक शिक्षिका इतिहास तथा बौद्ध अध्ययन विभाग पाटन संयुक्त क्याम्पस 


\section{परिचय}

उपत्यकामा गुँला महिनालाई धर्म अभ्यास गर्ने महिनाको रूपमा चिनिन्छ। यस महिनाभरी उपत्यकावासी आ-आफ्नो श्रद्धा र क्षमताअनुसार धर्म अभ्यास गर्ने गर्दछ्द्। बौद्वहरू मात्र नभएर हिन्दु सम्प्रदायका अनुयायीहरू पनि आ-आफ्नो परम्पराअनुसार धर्म अभ्यास गर्छन्। बौद्वहरूमा पनि थेरवाद, महायान र वज्रयानका अनुयायीहरू पनि आ-आप्नो तरिकाले धर्म अभ्यास गई्छन्। थेरवादीहरूको वर्षावास शुरू भएको पन्ध्र दिनपछि, यो गुँला महिना शुरू हुन्छ। गुँला महिना शुरू भए पछि, उपत्यकाको प्राय: जसो थेरवादी विहारहरूमा भगवान बुद्धबाट देशना भएको धर्म उपदेश, प्रवचन, ध्यान, परित्राण, दानप्रदान जस्ता विभिन्न कार्यक्रमहरू हुने गर्दछ। त्यस्तै महायान तथा वज्रयान अनुयायीहरू स्वयम्भू महाचैत्य, चैत्य, बहिल, विहार र महाविहारहरूमा उपत्यकाका विभिन्न स्थानहरूबाट समूहगत रूपमा साँस्कृतिक बाजा (धा: धिमे) हरू बजाउदै स्तोत्र पाठ गर्दे दर्शन पूजा गर्न जाने गर्दछ् । स्तोत्र पाठ गर्दे चैत्य विहार परिसर परिक्रमा गर्ने गर्दछन्। आ-आफ्नो अनुकुलताअनुसार परिवारभित्रै वा टोलको सामुहिक स्थल वा विहारहरूमा ज्ञानमाला भजन, स्तोत्र पाठ, प्रवचन, नवग्रन्थ वाचन, र व्याख्या आदि कार्यक्रम संचालन गर्ने गर्दछ् । यसै गरी यो महिनामा थुप्रै साँस्कृतिक परम्पराको चाडपर्व र जात्राहरू पनि पर्दछ। जस्तै गठेमड़ल, नागपञ्चमी, पञ्जाष्टमी, गुपुन्हि, गाईजात्रा, मतया:, बहिद्यो ब्वयगु, जुगचह्ने आदि। यसरी यो गुँला महिना आध्यात्मिक हुनुका साथै संगीतमय, मनोरज्जनात्मक र रमणिय हुने गर्दछ।

\section{गुँलाधर्म मनाउनुको उद्देश्य}

चन्द्रमास तिथिअनुसारको पात्रोको एउटा महिनाको नाम गुँला हो। श्रावणशुक्लप्रतिपदादेखि भाद्रकृष्णऔंशी सम्मको एक महिनालाई 'गुँला' भनिन्छ। नेपालको मौलिक सम्वत् नेपाल सम्वत् चन्द्रमासअनुसार गणना गरिने पात्रो हो । यसमा पनि बाह्न महिनाको एक वर्ष नै गणना गरिन्छ भने तिन वर्षमा एक पटक अधिक मास अर्थात् अनला आउँछ। नेपालसम्वत्अनुसार कार्तिकशुक्लप्रतिपदाको दिन देखि नयाँ वर्षारम्भ हुन्छ। कछला, थिंला, पोहेला, सिल्ला, चिल्ला, चौला, बछला, तछला, दिला, गुँला, अँला, कौला आदि बाह्न महिनाको नाम हो । जसअनुसार गुँला दशौँ महिनामा पर्दछ। यी बाह्र महिनामध्ये गुँलाको आफ्नै महत्त्व रहेको छ। नेवारी भाषामा गुँ को अर्थ नौ र लाको अर्थ महिना हुन्छ। नेपाल बौद्ध परिषद्का अध्यक्ष बौद्ध बिद्वान् महिश्वरराज वज्रचार्यका अनुसार “गुँला दशौँ महिनामा परे पनि यस महिनामा महायान बुद्ध धर्मको महत्त्वपूर्ण ग्रन्थ नववैपुल्यसूत्र पाठ गर्ने गराउने र गुरु पुरोहितबाट यसको व्याख्या गराउने भएर गुँला भनिएको हो। साथै यस महिनामा महायानी बौद्ध धर्मको आराध्यदेव श्री स्वयम्भूमा दर्शन र पूजा गर्न जाने चलन रहेको छ। नेवारहरू स्वयम्भू जानेलाई 'स्यंगु वनेगु' भनेर भन्दछन्। नेवारहरूले शब्दलाई अपभ्रंश बोल्ने चलन छ। नेवारी भाषामा गुँको अर्थ पहाड र जड्नल पनि हो, अतः पहाड वा जङ्नलमा रहेको स्वयम्भूको दर्शन गर्न जाने महिनाको रूपमा पनि यस महिनालाई गुँला महिना भनिएको र साथसाथै सत्ययुगमा स्वयम्भूको उत्पत्ति भैसकेको धेरै समयकालपछि, शान्तिकराचार्यले कालान्तरमा कलियुगको समयमा मानिसहरूमा लोभ चित्त श्रृजना भै यस स्वयम्भू ज्योतिरूपमा क्षति पुच्याउन सक्ने कुरालाई ध्यानमा राखी यसलाई चैत्याकारमा छोपेर सुरक्षित गर्ने काम गरे ।"१ चतुर्मास समाप्त हुने

1 Mahiswar Raj Bajracharya. 'An Introduction on Gunla Dharma'. Youtube. Basanti Smriti Pratisthan. $9^{\text {th }}$ 
सकिमला पुन्ही अर्थात् कार्तिकशुक्लपूर्णिमाका दिन स्वयम्भू ज्योतिरूपलाई चैत्याकारमा छोपेर प्रतिस्थापनको कार्य पूर्ण गरेको, यसको नौ महिना पछि गुँला महिनामा वर्षा ऋतु भएकोले अतिवृष्टि जस्तो दैवी प्रकोप र रोग व्याधि फैलने हुँदा यस्तो दैवी प्रकोपबाट बच्न स्वयम्भूको महिमा दर्शाइ गुँलाधर्म गर्ने प्रचलन चलाएको हुनु पई $।^{2}$ बौद्ध विद्वान् सद्धर्मराज वज्राचार्यज्यूले यशोधर महाविहारको धर्मागारमा गर्नु भएको 'गुँलाया धर्म देशना' का अनुसार गुँला को अर्थ “गुरुणा कथेन ज्ञानेन, पालयतीति रक्षतिती" भनेका छन् । जसको अर्थ गुरुले आज्ञा गर्नु भएको बुद्धको ज्ञान पालना गरी धर्म गरी राख्ने र बुद्धधर्मको शील पालना गरी शीलको रक्षा गरी राख्नेलाई गुँला भनिएको छ। यसमा पनि प्रतिपदादेखि पूर्णिमासम्मको पहिलो पन्ध्र दिन शुक्लपक्ष अर्थात् गुँलाथ्वलाई धर्मराग र त्यसपछिको गुँलागा कृष्णपक्षलाई 'क्लेश वितराग' भनिन्छ। अर्थात् गुँला महिना भनेको धर्मकार्य गरेर क्लेश समाप्त गरी बोधिचित्तोत्पाद गर्ने महिना हो ।

\section{गुँला धर्मको प्रचलन}

नेपाल मण्डलमा मानव बस्तीको विकाससँगै महायान बुद्धधर्मको बाहुल्यता रहेको देखिन्छ। महायान बुद्धधर्मको प्रमुख ग्रन्थ स्वयम्भूपुराणअनुसार महामज्जुश्रीले दहको पानी सबै बाहिर पठाएर मानव बस्तीको विकास गरिसकेपछि पानीको बहावसँगै दहबाट बाहिरिएका कुलिक नागराजले आफ्नो वासस्थान क्षतिग्रस्त बनाएको कारण रिसले अरु नागहरूसँग छलफल गरी फेरी यथावत् दह बनाउने उद्देश्यले चारुगिरी पर्वतमा बसेर अतिवृष्टि गराए। अरु नागहरूलाई पनि पानी बाहिर जाने निकास बन्द गरेर बस्न लगाए। यसले गर्दा उपत्यका जलमग्न हुँदे गयो। यहाँ बसोवास गरेका मानिसहरू अतिवृष्टिबाट डराएर वर्षा रोक्न विभिन्न किसिमका धर्मकर्म गर्न थाले। आर्यावलोकितेश्वर करुणामयलाई यस विपतबाट आफूहरूलाई रक्षाको लागि पुकार गर्न थाले। यस नेपाल मण्डलवासीले गरेको पुकार आर्यावलोकितेश्वरले ध्यान दृष्टिबाट हेरे। त्यसपछि, वहाँ आर्यावलोकितेश्वरले समन्तभद्रक बोधिसत्वलाई बोलाई चारुगिरी पर्वतमा बसेर अतिवृष्टि गराई राखेका कुलिक नागलाई शान्त पारी नेपाल मण्डलवासीलाई उद्वार गरेर आउन आज्ञा दिए । आर्यावलोकितेश्वरको आज्ञाअनुसार समन्तभद्रक बोधिसत्व चारुगिरी पर्वतमा पुगेर कुलिक नागराजको टाउकोमा बज्रकिल ध्वजा गाडिदिए र साथै यो गुँला महिनाको समयमा अतिवृष्टि गराई मानिसहरूलाई किन दु:ख दिएको, यसलाई चाँडै रोक ! यसप्रकारको कार्यले तिमी नरकगामी हुनेछौ भने पछि, कुलिक नागराजले क्षमा याचना गरी वृष्टि रोके, साथै निकास बन्द गरी बसेका अरु नागहरू पनि आ-आफ्नो बाटो लागे। समन्तभद्रक बोधिसत्वले कुलिक नागराजलाई केशावती र बिमलावती नदीको संगमस्थलमा वास गर्नु तिम्रो मनोकामना पूर्ण हुनेछ, भनी आशिर्वाद दिएर आफ्नो भूवनमा फर्के । आजसम्म पनि अष्ट वैतरागको अष्टमी व्रतको सिलसिलामा चाँगुमा व्रत गर्दा गुरू पुरोहितले यो कथा सुनाउने

\footnotetext{
Aug. 2019. Access on $5^{\text {th }}$ Nov. 2020.

https://www.youtube.com/watch?v=ZIPsn_UdqpE\&t=451s

२ रत्नकाजी बज्राचार्य, 'गुँला धर्मयात दुवाला ३२-४४', पलेख्वाँ, अड़क ७, वि.सं. २०४१, पृ. ३३।

३ सधदर्मराज बज्राचार्य, 'गुँलाया धर्म देशना १५-२प' पलेस्वाँ, अड़ १९, वि.सं. २०४६, पॄ. १६।

४ बद्रीरत्न बज्राचार्य, श्री स्वयम्भू महापुराण, काठमाडौं : जोगराज शाक्यवंश, ने.सं. १११६, पृ पू७-६१।
} 
गर्दछ् । यसबाट नेपाल मण्डलमा मानव वस्तीको विकासको समयदेखि नै यहाँ महायान बुद्धधर्म र गुँलाधर्मको अभ्यास गर्ने परम्परा रहेको बौद्धहरू विश्वास गर्दछन्।

\section{गुँलाधर्म मनाउने मान्यताहरू}

9) गुँला (श्रावण) महिना विशेषतः गर्मी र वर्षात्को महिना हो । यो महिनालाइ वर्षा बाढी पहिरो आउने र विभिन्न रोग ब्याधी फैलिने प्राकृतिक प्रकोप हुने महिनाको रूपमा लिईन्छ। यस्ता अप्रत्यासित रूपले हुने धनजनको क्षति र प्राकृतिक बिपत्तिबाट बच्न सकियोस् भन्ने अभिप्रायले मानिसहरू धर्मकर्मको अभ्यास गर्ने गई्छन्।

२) नेपालमण्डलका वासिन्दाको प्रमुख पेशा कृषि हो। यी कृषकहरूबाट रोपाईको कममा नचाहिकन पनि खेतमा कतिपय किटपतझ्नहूको हत्या हुन गएको हुन्छ। यसरी अन्जानमा हुन गएको हत्याको पापको प्रायश्चितको रूपमा ती मारिएका प्राणीहरू सद्गतिमा परोस् भन्ने कामनासहित यो धार्मिक कार्यक्रम मनाउने गरिन्छ।

३) उपत्यकामा गठेमझलसम्ममा रोपाईको काम सकिसकेको हुन्छ। यसरी रोपाईको काम सकेर फुर्सद भएको र खेतमा लगाएको अन्नवाली राम्रो होस् भन्ने अभिप्रायले रमाईलो गरी धार्मिक कार्यक्रमहरू गरेर मनाउने गरिन्छ ।

४) भगवान बुद्धले बुद्धत्व प्राप्त गर्नु भएपछि पहिले त वहाँले मैले प्राप्त गरेको ज्ञान अति गम्भीर छ, तृष्णा र मोहमा डुबेका (भुलिरहेका) मनुष्यहरूले यो धर्म दर्शन बुक्तन सक्ने छैन भनी उपदेश गर्नको लागि निरुत्साहित भएको थियो। तर सहम्पति ब्रम्हाले यस लोकमा तृष्ण बुद्धि भएका गम्भीर धर्म दर्शन बुऊनसक्ने अल्प क्लेश युक्त व्यक्तिहरू पनि छन् धर्म श्रवण गर्न नपाएर उनीहरूको जीवन व्यर्थ जानेछ। धर्म देशना गर्नु होस् भनी आग्रह गरेपछि आषाढ पूर्णिमाको दिन पञ्चभद्रवर्गिय श्रमणहरूलाई उपदेश दिई देवब्रम्हा मनुष्य आदि सबैको लागि उपदेशको द्वार खोलको थियो। यसरी धर्म श्रवण गर्न पाईने भएको उपलक्ष्यमा यो गुँला महिनामा धार्मिक कार्यक्रम गर्ने चलन भएको पनि कथन रहेको छ।

\section{गुँलाधर्मका अभ्यासहरू}

9) तीर्थ स्नान :- भक्तजनहरू बिहान सबेरै उठेर पवित्र नदी वाग्मती, विष्णुमतीमा गई स्नान गर्ने गर्दछन् । यसले शरिरीक र मानसिक रूपमा शुद्धि गर्ने र स्फुर्ति बढाउन मद्दत गरेको हुन्छ। तर आज भोली नदी प्रदुषित भएकोले नदीमा गई स्नान गर्ने चलन हराई सकेको छ। तर पनि घरमै स्नान गरेर देवस्थलहरू भ्रमण गरी दर्शन पूजन गर्ने गर्दछ् । पाटनमा बिहान सबेरै बौद्ध गीत गाँउदै चैत्यहरू दर्शन गर्न जाने परम्परा छ। यसलाई 'बागी वनेगु' भन्दछ् ।

२) चैत्य परिक्रमा :- टोल टोलबाट समुहगत रूपमा सास्कृतिक बाजाहरूका साथ स्वयम्भू तथा अन्य बहा: बही र चैत्यहरूमा स्तोत्र पाठ, पंचोपचार पूजा, परिक्रमा गरी त्रिकालका बुद्ध बोधिसत्वहरूको गुण स्मरण गर्दे आभार व्यक्त गर्ने गर्दछ्। । वहाँहरूको जस्तो गुण आफुमा पनि विकास होस, बोधिसत्व चर्या गरी जगत उद्वार गर्न सकूँ भन्ने कामना गरी चैत्य परिक्रमा गर्ने गर्दछन् । 
३) बुद्धपूजा र धर्मदेशना :- विहारहरूमा बुद्ध, धर्म, संघको गुण स्मरण गर्दे आमिष र प्रतिपत्ति पूजा गरिन्छ। भिक्षु र गुरुमाँहरूबाट धर्मदेशना सुनी उपासक उपासिकाहरूले मनमा प्रज्ञाज्योति जगाउने गई।

४) सद्धर्मपाठ:- महायानी तथा वज्रयानी महाविहारहरूमा महायान बुद्धधर्मको नवग्रन्थहरू -प्रज्ञापारमिता, ललितविस्तर, लंकावतारसूत्र, सद्धर्मपुण्डरीकसूत्र, सुवर्णप्रभाससूत्र, तथागतगुह्यक, दशभूमिश्वर, गण्डव्यूह र समाधिराजसूत्र पाठ गर्ने र विज्ञहरूबाट यसको व्याख्या गर्ने गराउने गरिन्छ।

y) व्रत उपवास बस्ने: - यस गुँला महिना भरी भक्तजनहरू आ-आफ्नो ईच्छाअनुसार व्रत उपवास गर्ने गर्दछ् ।

क) गुँला महिना भरी एक महिना नै दिनको एक छाक मात्र खाएर यों अवसं अर्थात् दैनिक व्रत बस्ने गर्दछ्। ।

ख) गुँला महिना भरी पाँच दिनको एक छाक मात्र खाएर न्यान्हु अवसं अर्थात् पाँच दिने व्रत बस्ने गर्दछन् ।

ग) विहारमा गई गुँला महिना भरी त्यही बसी गन्धुरी देवताको जल, दिनको एक पटक मात्र सेवन गरी अरु सबै आहार त्याग गरेर माय् अवसं अर्थात् मासव्रत बस्ते गर्दछ् । ${ }^{4}$

घ) आर्यावलोकितेश्वरको नाममा उपोसथव्रत बस्ने गर्दछ् ।

६) शील पालना : - यस गुँला महिना भरी पन्चशील तथा अष्टशील पालना गरी शुद्ध धार्मिक जीवनको अभ्यास गर्दछ् । मद्य, मांस र धुम्रपान आदि त्याग गर्ने गर्दछन् ।

७) त्यागशील: - दश अकुशल कर्मबाट अलग रहने उद्देश्यले कुलतहरू त्याग गरी शील, समाधि र प्रज्ञाको अभ्यास र दश कुशल कर्मको अभ्यास गर्ने गर्दछ् ।

द) बही द्यो ब्ययगु: - गुँला महिनामा विहार र बहिलहरूमा रहेको पौराणिक तथा ऐतिहासिक महत्त्व भएको बुद्ध बोधिसत्व दीपंकरहरूका मूर्ति, पौभा: तथा ग्रन्थहरू प्रदर्शन गर्ने चलन छ। यी धार्मिक महत्त्वका वस्तुहरू अरु बेला दर्शन गर्न नपाईने भएर यस अवसरमा थुप्रै भक्तजनहरू हेर्न जान्छन् ।

९) दान प्रदानका कार्यक्रमहरू: - भक्तजनहरू आ-आफ्नो ईच्छाअनुसार दान प्रदान गर्ने कार्यमा संलग्न हुन्छन्। विशेष गरेर पाटनमा श्रावणशुक्लअष्टमी र अन्य स्थानमा भाद्रकृष्णत्रयोदशीका दिनमा दान प्रदानको कार्य गरीन्छ। यो दिनमा श्रद्धालु भक्तजनले भव्य दानशाला बनाई नराँ अर्थात् नवदान पर्व समेत मनाउने गर्दछ् ।

\section{गुँला महिनामा पर्ने धार्मिक र साँस्कृतिक पर्व तथा जात्राहरू}

नेपाल मण्डलका वासिन्दाहरू वर्ष भरीमा थुप्रै जात्रा तथा पर्वहरू मनाउने गर्दछन्। त्यसमध्ये यो गुँला महिनामा आयोजना गरिने केही जात्रा तथा पर्वहरूको विवरण यसप्रकार छन् ।

१) लुचिद्यो थायगु - श्रावणशुक्लप्रतिपदादेखि भाद्रकृष्णऔंशीसम्म एक महिना, भक्तजनहरू शुद्ध भएर लुचिद्यो थायगु भनेर कालो माटोको स-सानो चैत्य साँचोमा राखेर बनाउने चलन रहेको छ। यसलाई 'लक्ष्य चैत्य' पनि भनिन्छ। यसरी लुचिद्यो बनाउने कतिपय स्थानहरूमा गुठी नै हुने गरेको छ भने कतिपय भक्तजनहरू आफ्नो

4 तीर्थरत्न शाक्य, 'गुँला पर्व-धर्म अभ्यासको पर्व', नेपाल मण्डलका बौद्धहरूको धार्मिक अभ्यास र जीवन शैली, काठमाडौं : बुद्धधर्म अध्ययन गोष्ठी, वि.सं. २०६४, पृ ४३-४६। 
स्वेच्छाले यसको आयोजना गर्ने गर्दछन्। यो लुचिद्यो एक महिनामा एक लाख पचीस हजार बनाउने भन्ने प्रचलन छ। लुचिद्यो बनाउन इच्छुक जो कोही पनि शुद्ध भएर आयोजना स्थलमा गई आफ्नो इच्छाअनुसारको संख्यामा बनाउन सकिनेछ। यसरी बनाइएका लक्ष्य चैत्यलाई पछि कुन निर्माणाधीन ठूलो चैत्यको गर्भमा निदान गरिन्छ, अथवा बगेको खोलामा लगेर विसर्जन गर्ने गरिन्छ। १ $^{\text {ह }}$

२) नागपन्चमी - श्रावणशुक्लपन्चमीको दिन बासुकी नाग लगायत नौ नागहरूको पूजा गरिन्छ। नागहरूको गुण स्मरण गरी घरको मूल ढोका माथि नागको चित्र टाँसेर पूजा गर्ने गरिन्छ। यसरी नागहरूको पूजा गर्दा नागको दोष निवारण हुने, नागको भय नहुने, चट्याङ्ले नछुने र घरमा दुर्भिक्ष हटेर शुभ मझ्गल हुने विश्वास गरिन्छ। यो दिन ललितपुर धापाखेल को नागदहमा ठूलो मेला लाग्ने गर्दछ।

३) पज्जाष्टमी - बुद्धधर्ममा दानको ठूलो महत्त्व छ। दशपारमितामध्ये दानपारमिता पहिलो पारमिता हो । महायान बुद्धधर्ममा गृहस्थ भिक्षुहरूको परम्परा रहेको कारण उनीहरूको लागि दैनिक दान लिन जानु र दिनु व्यवहारिक छैन। त्यसैले दान कार्यको लागि उपयुक्त दिनहरू भने दान गाथामा उल्लेख गरिएको छ। ${ }^{\natural}$ यसरी

६ लोकरत्न शाक्य, 'लक्ष चैत्य (लुचिद्य:) थायगुया महत्व व परम्परा २७-३१', २४६३ औं बुद्ध जयन्ती लुमन्ति पौ स्मारिका, वि.सं. २०७६, पृ २६-२९।

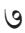

$$
\begin{aligned}
& \text { "कृत श्रावण पूर्वान्हे कृष्णपक्ष त्रयोदशी, } \\
& \text { माघे पूर्णेपि मध्यान्हे त्रेतानाम युगोदय:, } \\
& \text { बैशाख शुक्ल सन्ध्यायां द्वापरंच तृतीयक:, } \\
& \text { कार्तिक शुक्ल नवन्यां अर्धरात्रौ कलियुग्युग, } \\
& \text { ए ते युगोदये दान दद्याद्वै द्विपदोत्तमे" }
\end{aligned}
$$

विकास रत्न बज्राचार्य, (सं), बौद्ध स्तोत्र संग्रह, काठमाडौं : नेपाल बौद्ध संस्कृति संरक्षण केन्द्र, ने.सं. ११३४, पृ. २६१ ।

"कार्तिके शुक्ल नौम्यां च अर्धरात्रौ सत्ययुग:

माघे पूर्णोभि मध्यान्हे त्रेतानाम युगोदयः।

बैशाखे शुक्ल सन्ध्यायां द्वापरज्च तृतीयके

श्रावण कृष्ण पूर्वान्हे त्रयोदस्यां कलिर्युग,

एते युगोदये दान: दद्याद्वै द्विपदोत्तमे

सर्वेषां पुण्य संख्यास्ति तेषां संख्या नविद्यते ॥"

नेपाल परम्परागत बौद्धधर्म संघ, आर्य नामसंगीति गाथा व धारणी स्तोत्र संग्रह, यल: नेपाल परम्परागत बौद्धधर्म संघ, वि.सं. २०पू६ पू. पू७।

सूर्यप्रसाद ढुड़ेल (सं), सूर्य पन्चाड़ २०७७, काठमाडौं : सूर्यप्रसाद ढुड़ेल, वि. सं. २०७७, पृ. ३३ ।

पाटनको पन्चदानको दिन तथा अन्य दान कार्यक्रममा ललितपुरमा यही दान गाथा गाएर दान लिने चलन अद्यापि चलिराखेको छ। बसन्ती स्मृति प्रतिष्ठानबाट youtube मा प्रसारित ‘गुँलाधर्म एक परिचय' मा अध्यक्ष महीश्वरराज वज्रचार्यले जुगादी नवमी (कार्तिक शुक्ल नवमी) हेमन्त ॠतुमा पर्ने र यो ऋतुमा अति जाडो र अति गर्मी नहुने प्राकृतिक भय आदि पनि नहुने हुँदा यस दिनलाई सत्य युगको उदय भएको दिनको रूपमा मनाउने गरिन्छ भनेका छन् । यति मात्र नभएर यो ऋतुमा फूलहरू फूलेर प्राकृतिक रूपमा नै मन मोहक र आनन्द दायक हुन्छ। फेरि यसबेला अन्न फलफूलहरूको उब्जनी हुने समय भएर प्राणीहरूमा 
चतुर्युग उदय भएको दिनमा दुइ गोडाले टेक्नेहरूमा उत्तम अर्थात् बुद्ध बोधिसत्वहरूलाई दान गरेमा अपरिमेय पुण्य प्राप्त हुन्छ भनी दान गाथामा उल्लेख गरिएको छ। यी चतुर्युगका साथै सर्वानन्द नृप जातकका अनुसार श्रावणशुक्लअष्टमीको दिनलाई पनि दानकार्य गर्न उत्तम दिन मानिन्छ। यही श्रावणशुक्लअष्टमीको दिनलाई ' पज्जाष्टमी' भनिन्छ। यस दिन ललितपुरवासी आफ्नो श्रद्धाअनुसार अन्न, फलफूल, औषधिजन्य फल र दैनिक उपभोगका सामानहरू दान गर्ने गर्दछ्। । शाक्य, वज्राचार्य भिक्षु र स्थविरहरू दान गाथा गाएर दान लिन जाने गर्दछ। यसरी दान गर्न गुठीहरू स्थापना गरी जग्गा जमिन दत्त राखी त्यसको आयस्ताले संचालन गर्ने गरिएको हुन्छ भने कतिपय श्रद्धालु भक्तजनहरूले आफै दानशाला बनाएर पनि पच्चदान कार्यक्रम गर्ने गरेको हुन्छ। अरुको दानशालामा गएर पनि जो कोहीले आफ्नो इच्छाअनुसार दान गर्न सक्छन् । दिन भरी यसरी दान कार्य संचालन गरी साँक फुद्यो अथवा फुबरे आएर दान लिएपछि दानकार्य समाप्त हुन्छ।

૪) बही घ्यो ब्वयगु - यहाँ बही घ्यो भनेको बही विहारमा भएको देवता र ब्वयगु भनेको प्रदर्शन गर्ने हो। यो पर्व श्रावणशुक्लदशमीको दिनदेखि भाद्रकृष्णदशमीको दिन सम्म १५ दिन आयोजना गरिन्छ। यस अवधिमा विहार र बहिलमा भएको दीपंकर, बुद्ध, बोधिसत्वका मूर्तिहरू, चैत्य, महत्त्वपूर्ण हस्तलिखित दुर्लभ ग्रन्थहरू पौभा:, तुलाँपौ, विलँपौ तथा अन्य चित्रहरू प्रदर्शन गरिन्छ। काठमाण्डौंको भगवान विहारमा भाद्रकृष्णप्रतिपदा अर्थात् गाईजात्राको दिन शतसाहश्रिका प्रज्ञापामिता ग्रन्थ प्रदर्शन गरिन्छ। यो महायान बुद्धधर्मको प्रमुख ग्रन्थ हो। अरु बेला यो दुर्लभ ग्रन्थ दर्शन गर्न पाइन्दैन ।

५) गुन्पुन्ति - गुन्पुन्हि अर्थात् क्वाटी पुन्हि यसलाई हिन्दु धर्मावलम्विहरूले जनैपूर्णिमा भन्ने गर्दछन् । यस दिन ललितपुरको कुम्भेश्वर महादेवलाई मध्यरातमा त्यही परिसरमा रहेको पोखरीमा विराजमान गराईन्छ अनि बिहान सबेरै देखि दिन भरी त्यहाँ मेला लाग्ने गर्दछ। भक्तजनहरू महादेवको साथै त्यस परिसरमा रहेका देवदेवीहरूको दर्शन पूजन गर्दछ् । फेरि ब्राम्हण पुरोहितबाट यज्ञोपवीतसूत्र ग्रहण गर्दछन्। बौद्ध धर्मावलम्बीहरू यो दिन महादेवलाई बोधिसत्वको रूपमा दर्शन गर्ने गर्दछ् । सर्वपाल आचार्यले कुम्भेश्वरमा बसेर वज्रपाणी बोधिसत्वलाई आव्हान गरी जप ध्यान गरी राखेको यस दिन उनको आराधनाबाट प्रसन्न भएर वज्रपाणी बोधिसत्वले दर्शन दिएर अष्टसिद्धिको वरदान दिएको भएर यो पूर्णिमाको दिन यहाँ मेला लाग्ने प्रचलन रहेको छ $1^{5}$ यो दिन नेवार समुदायमा नौ थरी गेडागुडी राखेर क्वाटी पकाई खाने गर्दछन्। अक यो दिन नौ चोटी नुहाएर, नौ जोर लुगा लगाइ, नौवटा टिका लगाइ, नौ थरी गेडागुडी राखी पकाएको क्वाटी नौ चोटी खाएर, नौ बाजाको स्वर सुनेर, नौ वटा विहार र बहिल दर्शन गर्न जानु पछ भन्ने चलन रहेको छ। 9 फेरी यही दिन उपत्यकावासीहरूले ब्याँजा:नके भनेर खेतको चार कुना वा घर बाहिर खुला स्थानमा भ्यागुतालाई खाना राखिदिने चलन छ। यहाँ ब्याँ भनेको भ्यागुता र जा:नके भनेको भात ख्वाउने हो । प्रचलनमा रहेको किवन्दती अनुसार

कुनै किसिमको दु:ख भय रहदैन । प्राकृतिक रूपमा प्राणीहरू स्वर्गिय आनन्दको अनुभव गर्ने गर्दछन् ।

५ सद्धर्मराज बज्राचार्य. 'गुँलाया धर्म देशना १५-२४'. पलेख्वाँ, अड़ १९, वि.सं. २०४५, पृ २३।

$९$ हेमराज शाक्य. 'यल नगरय् नेवा: तय्सं गुँला हनिगु थी थी नखः चख: व जात्रा पर्वया संक्षिप्त म्हसिका ३५-४१', न्यकूजात्रामतया: २०७० स्मारिका, वि.सं २०७०, पृ ३७। 
एक समय मानिसहरूलाई मारेर खान भनी आएको घण्टाकर्ण राक्षसलाई भ्यागुताले हिलोले भरिएको धापमा पुच्याएर मारी मानिसहरूलाई बचाएको थियो $1^{90}$ यही सम्भनामा भ्यागुतालाई यसरी खाना ख्वाएको हो। यही कुरालाई व्यवहारिक तथा बैज्ञानिक दृष्टिकोणले भन्ने हो भने खेतमा बाली लगाई सकेपछि, त्यसमा कीराहरू पर्ने गर्दछ। भ्यागुताले ती कीराहरू खाएर बालीको रक्षा गर्दछ। यसरी खेतमा लगाएको बाली रक्षा गरी दिएकोले सम्मान गरी खाना ख्वाएको हुनु पर्दछ।

६) सापरु (गाई जात्रा) पर्व र धँन्जली या: - यो पर्व श्रावणकृष्णप्रतिपदाको दिनमा मनाईन्छ । यस दिन हिन्दु धर्मावलम्बीहरू, वर्ष दिनभित्र दिवंगत भएका आप्ना मान्यवरहरूको मुक्तिको कामना गरी गाई अथवा बालबालिकालाई शृझारपटार गरी शहर परिक्रमा गराईन्छ। बौद्ध धर्मावलम्बीहरू यस दिन बिहान सबेरै उठेर शुद्ध भै व्यंग थुर का:वनेगु भनेर आप्ना परिवारका सदस्यहरूको निर्वाणको कामना गरी ललितपुर नगरको चार कुनामा रहेको चार युगको प्रतिक चारवटा चैत्यमा दर्शन पूजन गर्न जाने चलन रहेको छ। मृतकका परिवार मात्र नभएर अन्य श्रद्धालु भक्तजन पनि प्यंग थुर दर्शन गर्न जाने गर्दछन् । यही दिन दिउँसो आ-आफ्नो घर चोक मुनि पेटीमा बसेर, विहार र बहीलमा गएर भिजाएको सानो केराउ, काक्रो, नासपाती, रुख कटहर आदि फलफूल दान गर्ने ख्वाउने र खाने गर्दछ् ।

७) मतया: - यो पर्व उपत्यकाको ललितपुर नगरमा मात्र श्रावणक्ष्णद्वितीयाको दिन मनाइने पर्व हो । तर यस जात्रामा उपत्यकाका अन्य स्थानका व्यक्तिहरू पनि सहभागि हुने गर्दछ। अभ आजकल त विदेशीहरू समेत यसमा सहभागी हुने गरेको पाइन्छ। मतया:को शाब्दिक अर्थ भन्नु पर्दा मत भनेको तेल वा घ्यूमा भिजाएर बालिने बत्ति वा चिराग र या: भनेको जात्रा वा यात्रा अर्थात् दीप जात्रा हो। यस पर्वलाई नेकू जात्रा पनि भन्ने गरिन्छ। नेकु अर्थात् जनावरको सिंग, यहाँ राँगाको सीङको बाजा बजाइने भएर नेकू जात्रा भनिएको हो । तर मतया: र नेकू जात्रा एकै दिन एउटै व्यवस्थापनले आयोजना गर्ने अलग अलग दुइ जात्राहरू हुन् । यो जात्रा ललितपुर शहरको 90 वटा टोलले आलो पालो गरी आयोजनाको जिम्मा लिने गर्दछ। मतया: अर्थात् दीप यात्रा वास्तवमा जात्राहरूको एउटा समूह नै हो ।

क) बोगी वनेगु - यो पर्व मतया: आयोजनाको पालो पर्ने टोलको आयोजनामा सम्पन्न गरिन्छ। श्रावणशुक्लप्रतिपदाको मध्यरात अर्थात् बिहान सबैरै करिब ३ बजे तिर शुरु गरी उज्यालो हुन थाले पछि, स्थागित गरिन्छ। फेरि भोलि बिहान सबेरै स्थगित गरिएको स्थानबाट शुरु गरी $\gamma / y$ दिनको यात्रा पछि, समाप्त गरिन्छ। बोगीको शाब्दिक अर्थ बुद्ध गीत गाएर यात्रा गर्नु हो। यो बोगी यात्रा मतया:को रुटमै विहार, बहिल, चैत्य, वसुन्धरा, आर्यावलोकितेश्वरको मन्दिर परिक्रमा गरी सम्पन्न गरिन्छ। यो जात्रा शाक्यमुनि बुद्धको पूर्वजन्मको श्रृझ्भरी अवदानसँग सम्बन्धित जात्रा हो । यसमा प्रमुख रूपमा राँगाको सीङको बाजा र यसको साथै धा:, धिमे, दमोखिं बाजा बजाएर बुद्ध गीत गाएर जाने गर्दछ। यसरी विहान सवेरै सीङ फुकी बाजाहरूका साथमा गीत गाएर नगर परिक्रमा गर्नुको धार्मिक मान्यताअनुसार दिवंगत भएकाहरूको सुगतिको कामना गर्नु हुन्छ भने अर्को यो १० वज्राचार्य, पूर्ववत् पादटिप्पणी नं. द, पृ २३। 
महिना बाढी, पहिरो, अतिवृष्टि हुने र विभिन्न रोग ब्याधिहरू फैलिएर चोरहरू बढने धनजनको क्षति हुने महिना भएकोले यस्तो सम्भावित दुर्घटनाबाट बच्न जागा भएर बस्नको लागि सचेतना स्वरूप यस्तो धार्मिक कार्यको आयोजना गरिएको भन्ने पनि भनाइ रहेको छ।

ख) मतया: - मतया: जात्राको उत्पत्तिको विषयमा भन्नु पर्दा, भगवान बुद्धले तपस्याको ऋममा मारगणलाई पराजित गरी बुद्धत्व प्राप्त गर्नु भएपछि, यस लोकमा बुद्धको उदय भयो अब सद्धर्म श्रवण गर्न पाइने भयो भनी खुशी भएर देव, ब्रम्हा, गर्न्धव, नाग आदि सबै चिराग बालेर बुद्धको दर्शन पूजन गर्न आएको सम्भनामा मनाएको पर्व भन्ने चलन छ, 199 त्यही भएर यस जात्रामा भक्तजनहरू चिराग बालेर आउने हो भनिन्छ। यो जात्रा कहिले देखि शुरु भएको भन्ने विषयमा यकिन प्रमाण भेटिएको छैन् तर देवमाला वंशावलीमा वालार्चन देवले ललितपुरको जेष्ठ वर्ण महाविहारको स्थापना गरी मतया: पर्व चलाएको भन्ने पाइन्छ। पटक पटक अव्यवस्थित भै बन्द प्रायः भैसकेको यो जात्रालाई राजा सिद्धिनरसिंह मल्लले व्यवस्थित गरी १० वटा टोलले आलो पालो गरी आयोजना गर्ने व्यवस्था गरेको देखिन्छ। जुन हालसम्म निरन्तर रूपमा चलिराखेको छ। यो पर्वलाई व्यवस्थित गरी सुचारु रूपले चलाउनुको पछाडी देशमा भयानक महामारी रोगलाई शान्त पार्नु रहको छ।

गुँलागा: द्वितीयाको दिन बिहान सबेरै आयोजना स्थलमा भक्तजनहरू जम्मा हुन्छन र करीव ४.३० बजे तिर गुरु पुरोहित र बाजाको अगुवाईमा जात्राको शुरुवात हुन्छ। यस जात्रामा हजारौं भक्तजनहरू पूजा सामग्री, खाद्य सामग्री, धुप दीप चढाएर सहभागी भएका हुन्छन। वर्ष दिन भित्र दिवंगत भएकाहरूको परिवारजनहरू मृतकको सद्गतिको कामना गरी स्तोत्र धारणीहरू छापिएको पर्चा, कपूर, बत्ती देवा आदि चढाएर आउने पनि चलन रहेको छ। धा:, धिमे, बाँसुरी आदि बाजाको सहभागिताले थप आकर्षण गरी राखेको हुन्छ अभ च्यालीको बीच बीचमा ख्याल: भनेर समय साक्षेप विकृतिहरूलाई व्यङ़ गरी विभिन्न भेषभुषा धारण गरेर आउने समुहले थप मनोरज्जन दिइराखेको हुन्छ।

ग) नवबाजा प्रदर्शन - मतया: पर्वको थप आकर्षण भनेको नवबाजा प्रदर्शन हो। नौ बाजा भनिए ता पनि यसमा धा:; धिमे, दमोखिं, नायखि, मृदंग, ढोलक, कोंचाखि, नगरा, ढ्यांग्रो, दह, मगखिं, जाडी नगरा, खैजरी, काशीबाजा, दक्षिणबाजा, सिंबाजा र डमरु गरी १७ थरी बाजाहरू समाबेश छन्। मतया:को दिन दिउँसो करिब दुइ बजेदेखि मतया: टोलकै आयोजनामा मतया: परिक्रमा गरिने टोलहरूको देवस्थल र डबलीमा गई पालैसँग नौ बाजा बजाइन्छ। यसरी नौ बाजाले नगर परिक्रमा गर्दा विभिन्न ३२ स्थानहरूमा बजाउनु पर्ने हुन्छ।१२ जुन करिव रात भरिको समय नै लाग्ने गर्दछ। त्यस स्थानहरूमा देवी देवता मन्दिरअनुसारको ग्वारा, राग, तालहरूमा मिलाएर बाजा बजाउने गरिन्छ। यो नौ बाजा मतया:को दिन ललितपुर नगरमा बजाउने बाहेक अन्य दिन र

११ महीश्वरराज बज्राचार्य, 'मतया:', सद्धर्म कथा सग्रह, भाग २, काठमाडौं : सजिव र अन्जना बज्राचार्य, वि.सं. २०७४, पृ ४६। १२ पन्चराज शाक्य, ललितपुरको मतया: पर्व एक अध्ययन, (स्नातकोत्तर अप्रकाशित शोधपत्र), लुम्बिनी : लुम्बिनी बौद्ध विश्वविद्यालय, वि.सं. २०७४, पृ ६५ । 
स्थानमा पनि बजाउनु पर्ने नियम रहेको छ। कुम्भेश्वर महादेवको स्थानमा, मल्ल राजदरवारको सुवर्ण ऊयाल मुनि, हनूमान्ढोका दरवार, स्वयम्भू महाचैत्य, रातो मत्स्येन्द्रनाको मन्दिरमा गई बजाउनु पर्ने नियम रहेको छ।

घ) गणेश पूजा र मतया: समापन - मतया: आयोजक टोलले मतया: पर्व सकिएको चार दिनपछि वा मड़लबार पारेर गणेश पूजाको आयोजना गर्ने गर्दछ। यसमा आयोजक टोलका परिवारहरूको सहभागितामा परम्परागत बाटोमा परेका गणेश मन्दिरहरूमा पूजा र खाद्य सामग्रीहरू समयबजि आदि चढाएर मनाइन्छ। बाटोमा परेका ४४ वटा गणेश मन्दिरहरूको परिक्रमा पश्चात् आयोजक स्थलमा आएर समापन गरिन्छ। यसको समाप्तिपछि, अर्को वर्षको आयोजक टोललाई पालो हस्तान्तरण गरी मतया: पर्वको समापन गरिन्छ।

๘) जुग:चह्ने - ललितपुरमा श्रावणशुक्लअष्टमीको दिन पन्चदान पर्व मनाए जस्तै उपत्यकाको अन्य स्थानहरू काठमाण्डौं, भक्तपुर, थिमी, आदि स्थानहरूमा जुग: चह्रे अर्थात् भाद्रकृष्णत्रयोदशीको दिन पञ्चदान पर्व मनाइन्छ। यस भाद्रकृष्णत्रयोदशीको दिनलाई चतुर्युगमध्ये कलियुगको उदय भएको दिन मानिन्छ। यस दिनमा गरेको दानको अपरिमेय पुण्य प्राप्त हुन्छ भन्ने मान्यता रहेको छ।

९) बुबाको मुख हेर्ने - गुँला महिनाको अन्तिम पर्व बुबाको मुख हेर्ने हो । यो भाद्रकृष्णऔँशीको दिनमा पर्दछ। यस दिन आप्नो जन्म दाता बुबाको गुणलाई स्मरण गरी बुबा जीवित हुनेहरूले सगुन, वस्त्र दिई मिष्ठान्न भोजन गराई मुख हेर्ने गर्दछ् भने, बुबा नहुनेहरूले सम्भव भए गोकर्णमा नभए बगेको खोलामा स्नान गरी निसला चढाएर मुख हेर्ने गर्दछन् तर अहिले खोला प्रदुषित भएको कारण घरमै स्नान गर्ने गर्दछन् । गुरु पुरोहितलाई निसला दिनुका साथै देवस्थलमा गएर बुबाको सद्गतिको कामना गरी देवा बाल्ने पूजा गर्ने गर्दछ् ।

१०) गुँला धर्मको समापन - गृहस्थ भिक्षुहरूलाई सधैं शील पालना गरी बस्नु सम्भव हुँदैन। भाद्रशुक्लप्रतिपदाको दिन गुँला महिना भरि पालना गरिएका व्रत, धर्म देशना, ग्रन्थ व्याख्या आदि समापन गरिन्छ। गुँला महिनामा त्याग गरिएका मद्य, मांस धुम्रपान आदि पनि फुकाउने गरिन्छ। यसरी समापन गर्दा सामुहिक रूपमा गुँला पारु भोय् भनेर भोजको आयोजना गरी रमाइलो गर्ने पनि चलन छ।

\section{निष्कर्ष}

उपत्यकामा थुप्रै चाड पर्व र जात्राहरू आयोजन हुने गरेको छ। यसमध्ये गुँलाधर्म पनि एक हो। गुँला धर्म श्रवण गर्ने, अभ्यास गर्ने महिनाको रूपमा चिनिन्छ। यो बहु पक्षिय पर्व हो। यस महिनामा पूजा, पाठ, ग्रन्थ व्याख्या, चैत्य विहार दर्शन भ्रमण गर्ने, भजन किर्तन स्तोत्र पाठ गर्ने चलन रहेको छ। यो आध्यात्मकि समय साक्षेप धर्म अभ्यासलाई साँस्कृतिक रूप दिई मनोरज्जनात्मक ढड़ले मनाउने गरेको पाइन्छ।

\section{सन्दर्भ ग्रन्थ सूची}

ढ़ड़ेल, सूर्यप्रसाद (सं), सूर्य पच्चाइ़्र २०७७, काठमाडौं : सूर्यप्रसाद ढुड़ेल, वि. सं. २०७७। 
नेपाल परम्परागत बौद्धधर्म संघ, आर्य नामसंगीति गाथा व धारणी स्तोत्र संग्रह, यल: नेपाल परम्परागत बौद्धधर्म संघ, वि.सं. पृ. ।

बज्राचार्य, विकास रत्न (सं),, बौद्ध स्तोत्र संग्रह, काठमाडौं : नेपाल बौद्ध संस्कृति संरक्षण केन्द्र, ने. सं. ११३४। बज्राचार्य, बद्रीरत्न, श्री स्वयम्भू महापुराण, काठमाडौँ : जोगराज शाक्यवंश, ने.सं. १११६।

बज्राचार्य, महीश्वरराज, 'मतया:', सद्धर्म कथा सग्रह, भाग २, काठमाडौं : सजिव र अन्जना बज्राचार्य, वि.सं. २०७४।

बज्राचार्य, रत्नकाजी, 'गुँला धर्मयात दुवाला ३२-४४', पलेस्वाँ, अड़ ७, वि.सं. २०४१। बज्राचार्य, सधदर्मराज, 'गुँलाया धर्म देशना १४-२४' पलेख्वाँ, अड़क १९, वि.सं. २०४६। शाक्य, तीर्थरत्न, 'गुँला पर्व-धर्म अभ्यासको पर्व', नेपाल मण्डलका बौद्धहरूको धार्मिक अभ्यास र जीवन शैली, काठमाडौं : बुद्धधर्म अध्ययन गोष्ठी, वि.सं. २०६४ ।

शाक्य, पञ्चराज, ललितपुरको मतया: पर्व एक अध्ययन, (स्नातकोत्तर अप्रकाशित शोधपत्र), लुम्बिनी : लुम्बिनी बौद्ध विश्वविद्यालय, वि.सं. २०७४ ।

शाक्य, लोकरत्न, 'लक्ष चैत्य (लुचिद्य:) थायगुया महत्त्व व परम्परा २७-३१', २४६३ औं बुद्ध जयन्ती लुमन्ति पौ स्मारिका, वि.सं. २०७६।

शाक्य, हेमराज, 'यल नगरय् नेवा: तय्सं गुँला हनिगु थी थी नख: चखः व जात्रा पर्वया संक्षिप्त म्हसिका ३५-४१', न्यकूजात्रा-मतया: २०७० स्मारिका, वि.सं २०७०।

Mahiswar Raj Bajracharya. 'An Introduction on Gunla Dharma'. Youtube. Basanti Smriti Pratisthan. $9^{\text {th }}$ Aug. 2019. Access on $5^{\text {th }}$ Nov. 2020.

https://www.youtube.com/watch?v=ZIPsn_UdqpE\&t=451s 